\title{
Hydrogen Fuel cell vehicle for Mexico City
}

\author{
Stephen Samuel \\ Oxford Brookes University, United Kingdom

\begin{abstract}
Rogelio González Oropeza, Eduardo Cedillo Cornejo
\end{abstract} \\ Universidad Nacional Autónoma de México, México
}

Copyright $($ 20xx SAE International

\begin{abstract}
The search for alternative fuel for transport vehicles and also replacement of internal combustion engines in order to reduce the harmful emissions have been forcing the vehicle manufacturers to innovate new technology solutions for meeting the stringent legislative targets. Mexico's commitment for de-carbonisation of transport sector and meeting the environmental goals is shaping it especially, and with this, it favours the move towards electrification of the vehicles. The aim of the present work is to numerically evaluate the possibility of replacing the IC engine in the existing hybrid vehicles with the Hydrogen fuel cell system. This work modelled a Hydrogen fuel cell vehicle based on Toyota MIRAI and validated the fuel economy performance of the vehicle using experimental data. This validated model was used to estimate the fuel economy for real-world drive cycles generated in 2019 from Mexico City. It considered three different drive cycles representing real-world driving in the Metropolitan Area of the Valley of Mexico. This study estimated the amount of reduction in $\mathrm{CO} 2$ and other pollutants for the year 2020, and 2030 and 2040 if the IC engine in the electric hybrid vehicles is replaced with the Hydrogen fuel cell. The study also estimated the amount of Hydrogen fuel required for replacing the IC engines with the Hydrogen fuel cell for moving towards electrification of light duty vehicles.
\end{abstract}

\section{Introduction}

Recently, the move towards electrification of transport sector is seen by most of the policy makers as one of the best option for achieving zerocarbon or low carbon vehicles for meeting sustainable development goals and clean air targets. However, the advancement in the field of internal combustion engines towards improving fuel economy and reducing in exhaust levels was the main reason for hindering the population of electric vehicles since early 1900 [1]. In addition to these, national infrastructures, taxation and economic policies have been developed over the century around petroleum industries around the world. Stringent exhaust emission targets introduced for internal combustion engines have also forced the vehicle manufacturers to refine the existing technologies in the field of fuel injection and engine control and develop lightweight materials for improving the fuel

Page 1 of 10 economy for the complete powertrain and vehicle systems together. Therefore, the fuel economy of the current light duty vehicles is significantly higher than the vehicles produced 1970s [2]. In addition, the exhaust emission levels are far smaller than that of pre 90 s vehicles.

However, the levels of air pollution in cities had not decreased significantly mainly due to increased number of vehicles and the demand for fossil fuel, which are the main fuel source for the internal combustion engines. The levels of air pollution related illness and mortality are on the rise especially in the metropolitan cities around the world; therefore, the need for developing disruptive technology for zero emissions at the point of use for automotive sector is compelling. One of the successful technology, as an interim measure, that enabled the vehicle manufacturers to reduce the fuel consumption and reduce emission real-world emission levels significantly is the hybrid electric vehicle with regenerative braking systems. The transition to hybrid technology and time to develop control systems and efficient electric drives for automotive engines over two decades gives an excellent opportunity for moving in the direction of fully electrified vehicles for automotive sector to address local air pollution issues over the coming decades.

Moreover, the policy makers have two main options to choose the disruptive technologies that will demand major infrastructure [3] change or use the existing infrastructure for adopting new technologies for the vehicles or mixture of both. Fully electric, battery electric vehicle falls in one category and replacing the internal combustion engine with the fuel cell and keeping the entire hybrid vehicle configuration falls in another category. The second option will be best option for emerging markets where the market entry of hybrid vehicle is getting stronger. Replacing the internal combustion engine with the fuel cell system also gives option for various types of fuel mixture for fuel cells depending upon fuel availability in different countries [4]. Therefore, hydrogen fuel cell vehicle are entering the market gradually. In addition, the further research in life time of the fuel cell systems [5] [6], fuel source for hydrogen [7] [8] [9] [10] and materials for the fuel cell [11] [12] [13] cooling systems for the fuel cells are also being strengthened by researchers. All these areas need further development and can lead to breakthrough technologies. One of the main sources of hydrogen in the natural gas and the possibility of producing hydrogen from non-carbon source is attracting lot of attention in the research community. When this goal is achieved, it provides us opportunity for 
meeting sustainable environmental goals and clean air targets for better health. This added benefit can enable the nations to implement fuel cells for other applications [14]. Energy management systems used for existing hybrid vehicle can be used for optimizing the fuel economy of the fuel cell vehicle [15]. The researchers also identified in the 60s [16] that the vehicle weight will increase while moving towards fuel cell vehicle, however, that will be compensated by increase in fuel economy. The current fuel cell vehicle on the market confirms this prediction well. Considering these benefits, various countries are evaluating the option of fuel cell for the vehicle in order to improve the local air quality and capture the promising market segment [2] [3] [17] [18].

Converting an electric vehicle into fuel cell vehicle has been active area of research for some time [19]. However, the advantage of converting the Internal combustion engine to fuel cell offer more advantage to the nation for meeting the air pollution requirements and generating and converting fuel to electricity at the point of use for reducing the transmission losses. Fuel cell vehicle has been evaluated for other applications such as railways [20], distributed power network especially in the time of natural disaster and emergency [21] [22].

Therefore, the interest for optimizing the performance of the fuel cell system using numerical modelling [23], model based design [24], modelling hybrid vehicles with the fuel cells [25] is increasing rapidly. Most of the modelling approaches for fuel cell in the literature deals with the thermodynamic behaviour of the fuel cell stack [24] [26], lumped parameter for vehicle model to estimate the power required to drive the vehicle, and fuel cell model to estimate the fuel flow to meet the demand by evaluating individual systems. Limited amount of work in the recent literature deals with the integrated vehicle with the fuel cell model including regenerative braking and energy storage systems for evaluating the performance of the fuel cell vehicle [15] [20] [24] [27]. If we need to evaluate the fuel economy of the fuel cell vehicle in order to estimate the amount of reduction in $\mathrm{CO} 2$ and other emissions levels if an internal combustion engine in the hybrid vehicle is replaced by the fuel cell and all other systems are kept unchanged we need a dynamic model of the hybrid vehicle with regenerative braking and all existing energy management strategy.

This concept is also not a new one; many researchers [15] have been evaluating the performance of fuel cell vehicle and fuel cell vehicle with regenerative braking for estimating the reduction of $\mathrm{CO} 2$ for specific countries [2] [28]. Also using conventional backward kinematic model of the vehicle for estimating the fuel consumption and overall performance of the fuel cell vehicle for different drive cycles. These studies have some inherent limitations, since their models were developed before commercially available [29] [30] [31], production vehicles are available and or uses backward kinematic models [32] [33] [34] [35], which does starts its calculation at the wheels and proceed backward for estimating the power required from the single source of power out which cannot handle multiple of sources of power. In addition, limited number of studies also found in the literature in relation to load following characteristics of the fuel cell vehicle [36] and regenerative braking [37].

Therefore, the present work had three main aims; firstly to develop a representative fuel cell vehicle model and validate with the experimental data from commercially available fuel cell vehicle; secondly, develop representative drive cycles for the Mexico city; and finally, estimate the amount of hydrogen required if the internal combustion engines in the hybrid vehicle is replaced by hydrogen fuel and quantify the local air quality benefits for the proposal scheme.

\section{Methodology}

The scheme adapted for modelling a representative fuel cell vehicle for evaluating the fuel consumption for different drive cycle pattern for Mexico city is shown in Figure 1. The current work is based on Toyota MIRAI fuel cell vehicle, since sufficient amount of data and experimental results are available for validating the model LohseBusch et al [38]. The work assumes that the control logic for estimating torque and power required from fuel cell follows the control logic used in Toyota Prius Hybrid Electric Vehicle (Prius HEV) with regenerative braking system. The main difference between these two vehicles are the fuel cells in place of internal combustion engines and the vehicle mass of MIRAI is different from Prius hybrid vehicle. Therefore, a Toyota Prius Model validated by the one of the authors of this work, Samuel. S., [39] [40] was used in this current work. The vehicle mass of the Prius vehicle was replaced with the vehicle mass of MIRAI to generate the torque and power required from the internal combustion engine to drive the vehicle against NEDC drive cycle and US06 drive cycle since the experimental data for MIRAI for these drive cycle data was available for validation. The main purpose of using this model is to generate the torque required to drive the vehicle at a given engine speed based on forward dynamic approach using existing hardware and control logic present in the Prius vehicle. Therefore, this torque demand can be imposed on Fuel cell system assuming that the energy recovery from regenerative braking and energy storage capacity are maintained similar to that of Prius vehicle.

Once the torque and power demand from the internal combustion engine to drive the vehicle at every second was estimated for NEDC and US06 drive cycle, the fuel cell simulation was carried out for estimating the amount of fuel required for meeting the demand. Then the results were compared with the experimental data obtained from MIRAI fuel cell vehicle.

\section{Modelling hydrogen fuel cell vehicle}

\section{Vehicle modelling}

The vehicle model based on Prius consists of steady-state performance data based internal combustion engine model, power-split device, drive line systems, vehicle model, electric motor and generator units and battery management systems, regenerative braking systems and driver control. The model works based forward dynamic approach and therefore, for the given demand, in this case, vehicle speed at a given time, the model will estimate the power required to meet the demand and then based on the energy available from the battery and recoverable energy from regenerative system; it will identify the power demand from the internal combustion engine. Forward dynamic modelling approach accepts multiple energy sources in order to estimate the required power from the prime mover, in this case internal combustion engine. Therefore, the power demand from the internal combustion engine considering the energy available from available sources can be considered as the demand from the fuel cell if the existing supervisory control logics are not changed. This is the approach followed in the current work. This model was developed by Samuel.S., for evaluating the energy management strategy of Prius for their previous work [39]. 
More details on the ability of the model to follow any speed profile to simulate the transient performance of the engine and energy recovery system for predicting fuel consumption can be found in Hector et al [39] and Bengolia et al [40].
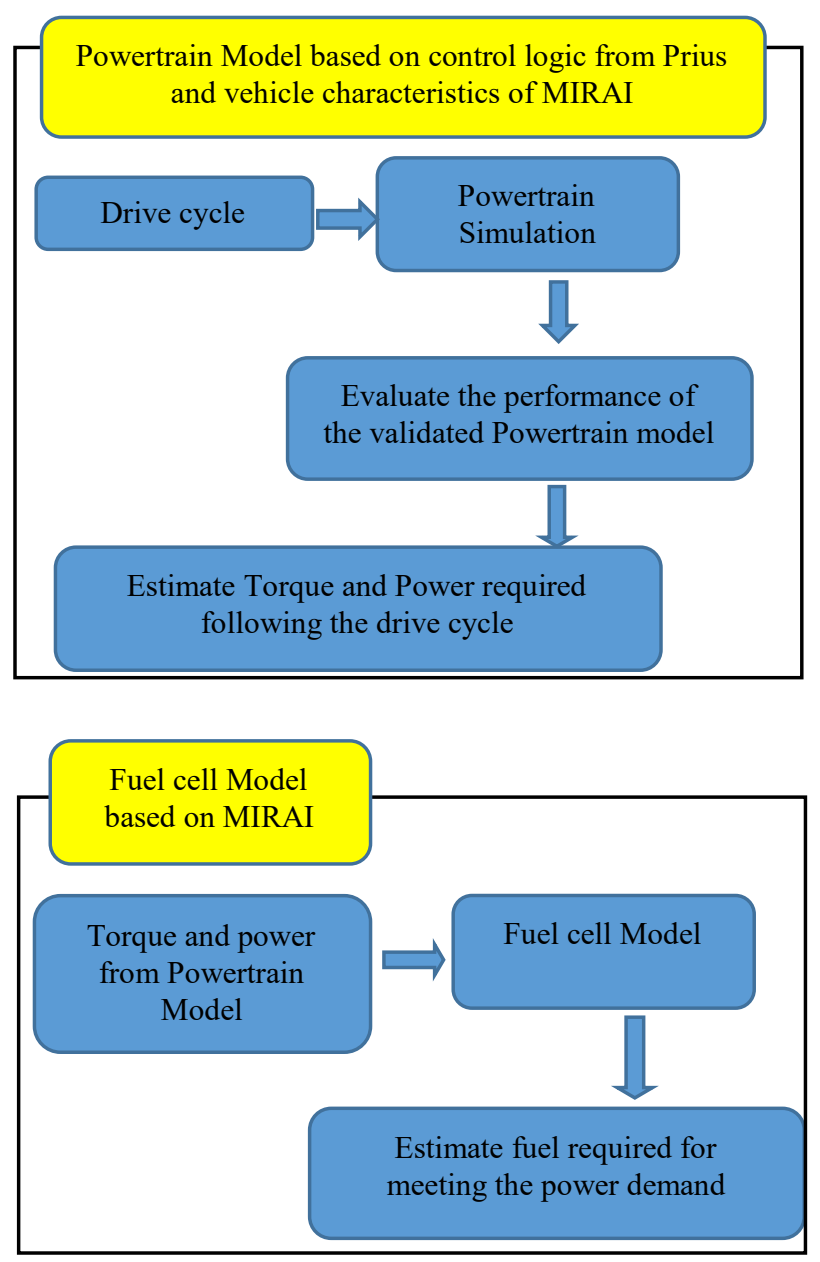

Figure 1. Modelling scheme adapted for Modelling MIRAI fuel cell vehicle.

The power demand in $\mathrm{kW}$ for meeting NEDC drive cycle and US06 drive cycles were estimated as shown in Figure 2. The output from this vehicle model was coupled to Fuel cell model. The details of the fuel cell model are described in the following section.

\section{Fuel cell modelling}

The vehicle considered for this study employs hydrogen as a fuel for the fuel cell. It is a Proton Exchange Membrane fuel cell. Fuel cell model in GT-Suite [GT-Suite, 2018] estimates the open circuit voltage based on Gibbs free energy of formation and estimates activation loss, mass transport loss, Ohmic loss for the given operating temperature to determine the voltage generated by the fuel cell for a given operating temperature. The input parameters required for modelling and the overall specification of the hydrogen fuel cell used in the model were obtained from Lohse-Busch et al [38]. The major components and

systems used for modelling the fuel cell in GT-Suite is shown in Figure 3.
The fuel cell model receives the instantaneous electrical power demand requested by the supervisory control of the vehicle. It estimates, Hydrogen consumption and Oxygen rate, water production rate, stack temperature and heat rejection from the stack for meeting the demand. Figure 4 shows the hydrogen consumption rate obtained from the model. This data was integrated for the duration of the drive cycle to obtain weighted fuel consumption in $\mathrm{kg} / \mathrm{km}$. A similar approach was followed for all other drive cycles.

\section{Validation}

The power required from the internal combustion engine in the hybrid vehicle for following the driving cycle as a function of time generated by the vehicle model was sent to the fuel cell model as shown in Figure 1. This is instantaneous electrical power demand in $\mathrm{kW}$ from the fuel cell for following the drive cycle. The fuel cell model estimates the instantaneous fuel flow rate required for meeting this demand. The instantaneous fuel flow rate estimated as a function of time for the entire drive cycle is integrated to obtain total mass of fuel consumed to follow the drive cycle. The total energy required for following the drive cycle consists of energy available from the energy storage system, energy recovered from regenerative system and energy required for overcoming the losses in the mechanical and electrical sub-systems. The total amount of fuel consumed by the fuel cell for the entire drive cycle in $\mathrm{kg} / 100 \mathrm{~km}$ was obtained from the model and compared against the experimental data obtained from Argonne National Laboratory data sets Lohse-Busch et al [38]. Two different drive cycles were chosen for the validation purpose based on the characteristics of the drive cycle. NEDC drive cycle is chosen for characterising low acceleration with moderate maximum power demand for following the drive cycle. In contrast, US06 drive cycle for characterising high acceleration with high power demand for following drive cycle. Therefore, if Prius vehicle model with existing battery system, energy recovery system and supervisory controls with fuel cell system of MIRAI is validated against the experimental data of MIRAI it will give confidence that the supervisory control used in MIRAI is not significantly different from Prius for following these drive cycles. Therefore, this validated model can be used for estimating fuel hydrogen fuel consumption for any drive cycle. It is already known that the Prius model with internal combustion engine developed by the authors of this work is capable of generating instantaneous power demand for following any real-world drive cycle [39]. Therefore, the only sub-system which needs to be validated following the drive cycle is the fuel cell system model developed for this work.

The experimental data correlates well with the results obtained from the simulation and is shown in Figure 5. The model was validated against NEDC drive cycle and US06 drive cycle. The model predicts the fuel consumption within $4 \%$ of the experimental data. It is within the testto-test variations reported from the experimental data. This validated model has been used for evaluating the hydrogen fuel required for following various cycles representing driving pattern and typical trips in Mexico City. The details of the drive cycles and the procedure used for developing the drive cycle for this purpose are explained in the following sections. 

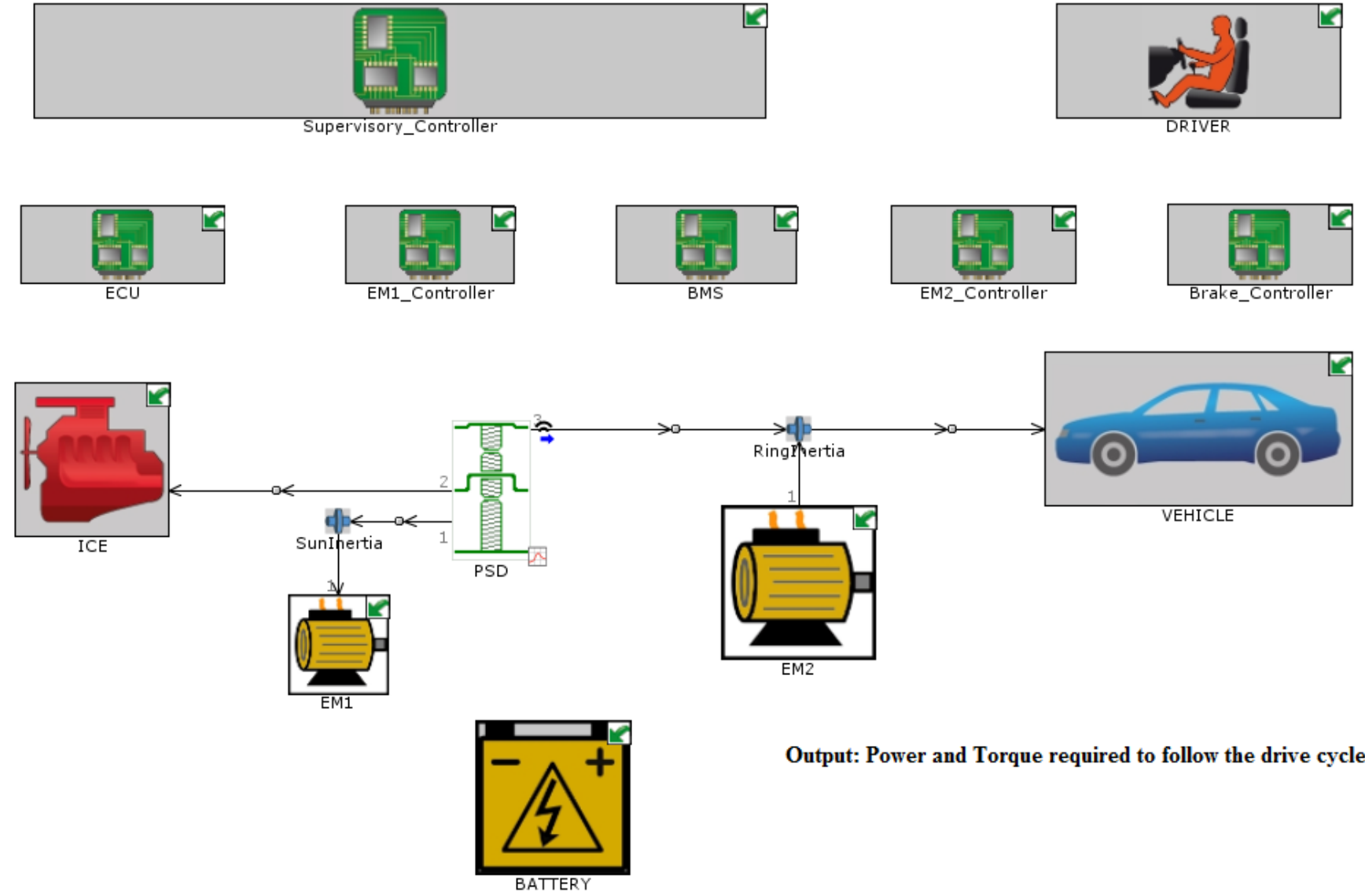

Output: Power and Torque required to follow the drive cycle

Figure 2. Powertrain Model representing components and systems of Prius in GT-Suite (ICE is replaced by PEMS in MIRAI model).

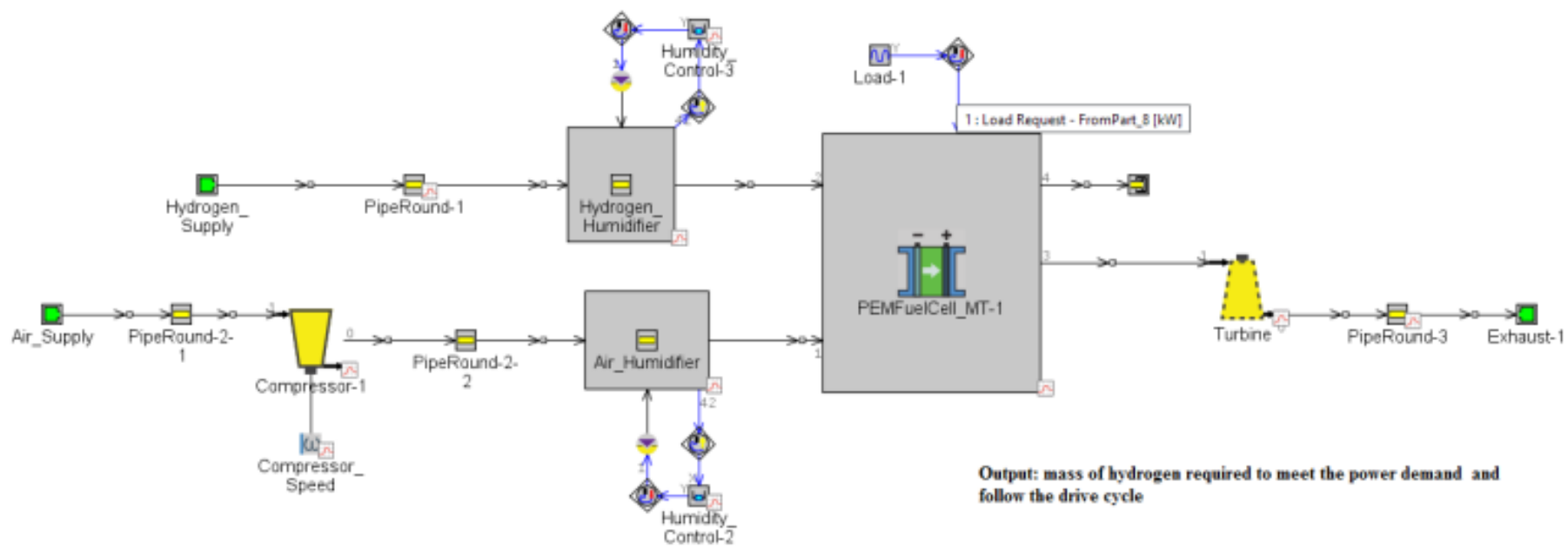

Figure 3. Fuel cell Model representing MIRAI fuel cell system in GT-Suite.

Page 4 of 10 


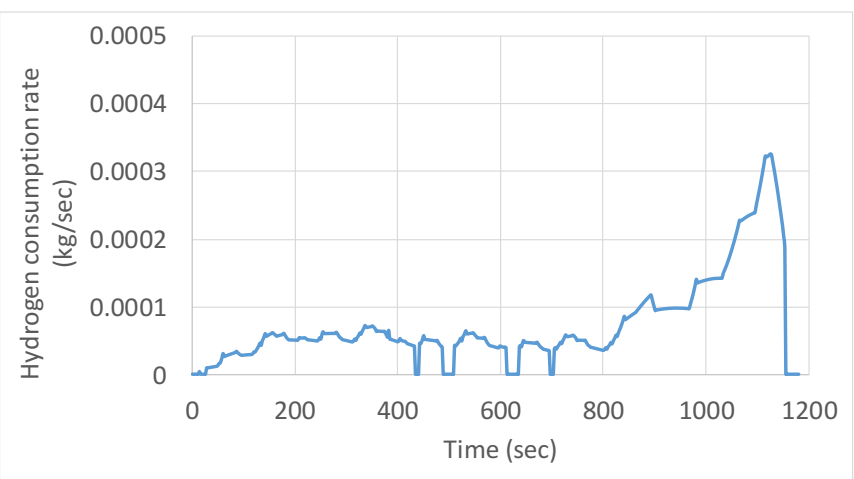

Figure 4. Hydrogen consumption rate from Fuel cell model for following NEDC drive cycle

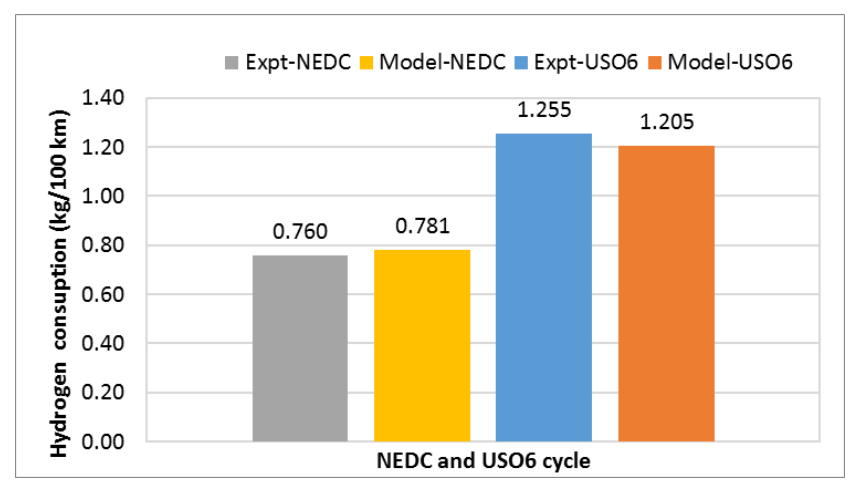

Figure 5. Numerical Model of MIRAI validated using experimental data.

\section{Development of Real-World drive cycle for MAVM}

Considering that driving cycles are a very important tool to measure pollutant emissions, among other objectives, UNICE research group based at UNAM developed a statistical method that synthesizes the data collected during the trips that people make to commute between home and work, school, and for other regular day to day activities. These data sets are used by UNICE to establish a representative drive cycle for Metropolitan Area of the Valley of Mexico (MAVM). The method includes; selection of a representative sample of vehicles, design and construction of equipment to record the route (coordinates), the speed of the vehicle and the slope of the road, the subsequent processing of data and the numerical synthesis of the driving cycle. The details of these stages, carried out for the creation of the driving cycles used in this study are explained in the following sections.

\section{Route and Vehicle Selection}

The first criteria in the process of developing the driving cycles was to limit the sampling region to the territory known as the Metropolitan Area of the Valley of Mexico (MAVM), which encloses 59 municipalities of Estado de México, 16 of Ciudad de México and 1 of Estado de Hidalgo, given that the territorial limits impose no interruption in the vehicular displacements that take place on the roadways that communicate these political entities, as the spread of urban infrastructure certainly does.
In order to build a driving cycle which contains information from the extra-urban, urban, and intra-urban regimes of transit, there was no discrimination of the roadways the sampled vehicles were to be requested to travel on; instead, volunteer drivers were selected for the sampling with preference for those who used to travel in highways, given the scarce occurrences of this road type found in comparison with the amount of people driving on urban and intra-urban regimes.

As for the representative sample of light duty vehicles in the MAVM, the "directorate of air quality management" of Ciudad de México has an inventory of manufacturers, models, classes and other details of the vehicles that transit in this city, that was used to create a classification of vehicular groups [41]. The vehicle groups were sorted by; registration year, number of engine cylinders and engine displacement. With this information, it was possible to statistically calculate a representative sample composed of 28 vehicles, with a reliability factor of 0.90 and a relative error of 0.15 that is within acceptable values.

\section{Data Sampling and Post-Processing}

Following the evaluation of costs and resources of the work team, the number and composition of volunteer drivers was chosen for the sampling of transit data. In addition, the vehicular driving tracker built in a portable housing with a dash power supply connector and a microSD memory slot, registered second-by-second: (1) the coordinates, (2) elevation, and (3) speed of the vehicle. The volunteer drivers were briefed on the handling of the tracker and carried it in their cars for a week, after which it was recovered and the collected data was analyzed. The post-processing of the CSV files collected by the tracker (1) to rearrange the significant columns of information to facilitate the reading done by the numerical synthesizer and (2) to create an adequate classification of the files in an inventory array for future consultation and publishing.

\section{Construction of Representative drive cycle}

From the accumulated 51 days of vehicular transit and the 5 car models evaluated on the representative sample of 28 cars, a total driving routine that contains the whole collection of micro-trips and slope information was created, which totaled a duration of more than 340 hours and a distance of $1220 \mathrm{~km}$. The process of synthesizing a representative driving cycle from this inventory of routines was accomplished with the programming of an algorithm developed by the work team and implemented in a Scilab procedure.

The algorithm developed, that consist of 4 stages, works as follows: reviews a total driving routine present in the working directory of the procedure and extracts its information into one array of micro-trips and another of slopes; calculates an array of "micro-trip indicators" such as total period, mean speed or period with positive acceleration; creates a catalog of micro-trips with their respective slope, sorted from the most representative to the least, for the 3 transit regimes; with the setting of a desired quantity of extra-urban micro-trips in the final drive cycle, concatenates from most representative to least the micro-trips needed to fill the same proportions of extra-urban, urban, intra-urban and static periods present in the total driving routine as shown in Figure 5.

This whole process, applied to the sampled data from MAVM, resulted in a drive cycle for light duty vehicles composed by 1 extra-urban, 4 urban and 6 intra-urban micro-trips, which totaled a duration of 1271 $\mathrm{s}$ and a distance of $9681 \mathrm{~m}$. The representative drive cycles developed are shown in Figure 6. The essential characteristics of the 4 drive cycles 
shown in Figure 6 are similar but varying in terms of duration of the drive cycle to represent the regular commuting in MAVM.
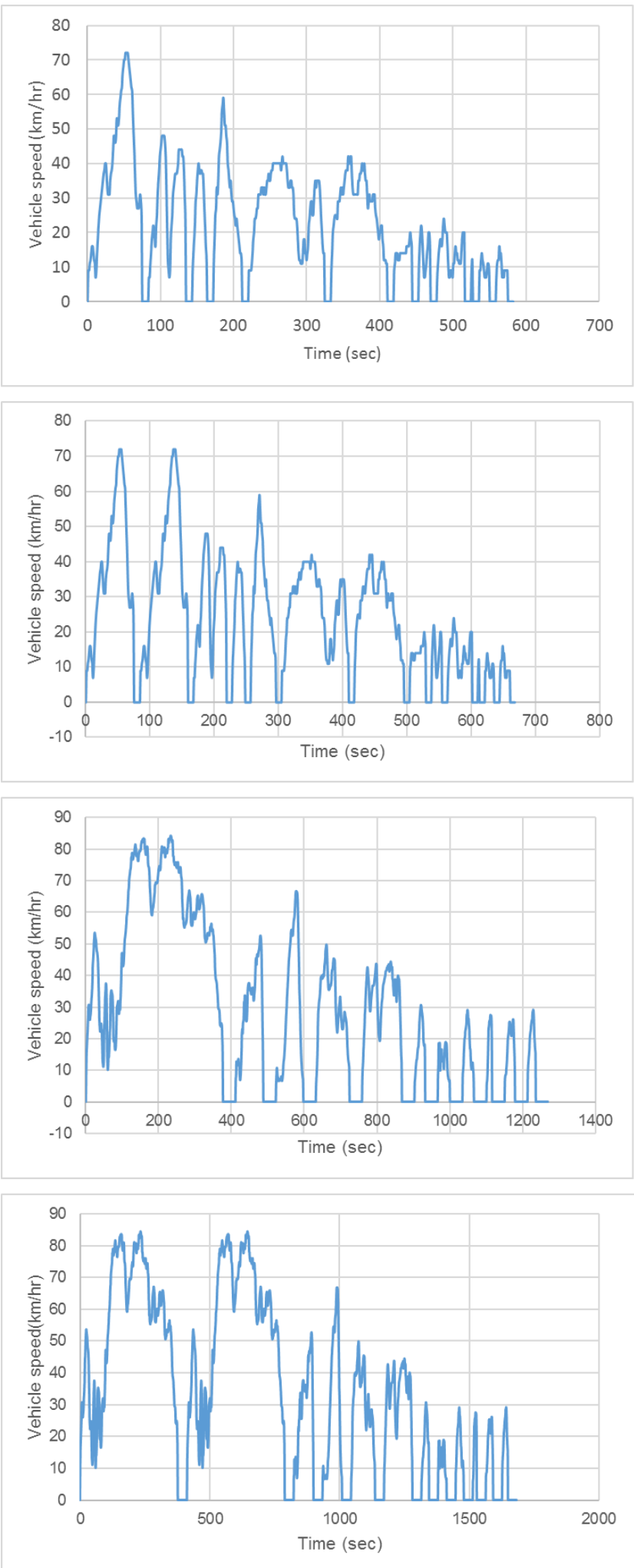

Figure 6. Representative real-world drive developed by UNICE for MAVM to represent different trip distances.

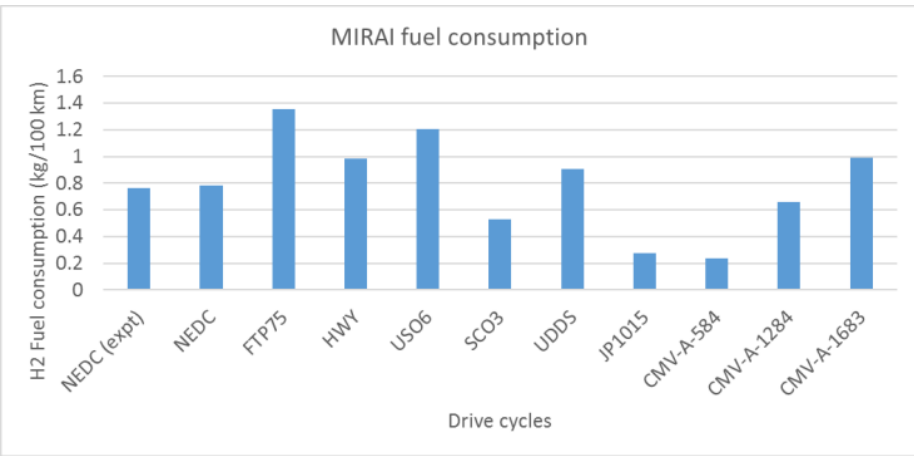

Figure 7. Hydrogen fuel consumption in $\mathrm{kg} / 100 \mathrm{~km}$ for various drive cycles using validated fuel cell vehicle model.

The validated fuel cell vehicle model was run using these drive cycles in order to evaluate the fuel consumption in $\mathrm{kg} / 100 \mathrm{~km}$ as shown in Figure 7. It can be seen that fuel required for following CMV-A-584 is very similar to that of Japanese 10-15 mode drive cycle. Similarly, CMV-A-1683 Mexican drive cycle is very similar to USA HWY drive cycle. The fuel consumption in $\mathrm{kg} / \mathrm{km}$ generated by this validated model for Mexico drive cycle is used for estimating total amount of fuel required for Mexico if the internal combustion engines in the hybrid vehicles are replaced by Fuel cell system.

\section{Number of Hybrid vehicles present in Mexico Metropolis area}

Therefore, total number of hybrid vehicles registered in Mexico since 2010 to present was obtained from (Dirección General de Registro Público de Transporte, a section of Secretaría de Movilidad de la Ciudad de México (SEMOVI)). It includes all types of hybrid vehicles from 22 manufacturers registered in Mexico Metropolis. The number of vehicles registered per year since 2010 and the cumulative count for total number of hybrid vehicles on the road since 2010 are shown in Figures 8 and 9 respectively. The rate of growth seems to follow exponential rate and therefore, the total number of vehicles on the road follows the exponential rate. It is difficult to extrapolate this rate and project the number of vehicle for the future even though the current trend follows the exponential rate of growth. However, the one can assume that the number of hybrid and electric vehicle in Mexico will increase significantly in the coming years. The present work assumed two scenarios for estimating and projecting expected emission reduction if the internal combustion engines in the hybrid vehicles are replaced by fuel cell system. Similarly, the amount of hydrogen supply required for servicing fuel cell vehicle fleet for planning hydrogen distribution system has also been studied for these two scenarios. The importance of government intervention for sustainable future for other countries similar to the current study is also found in recent publications [42] [43]. 


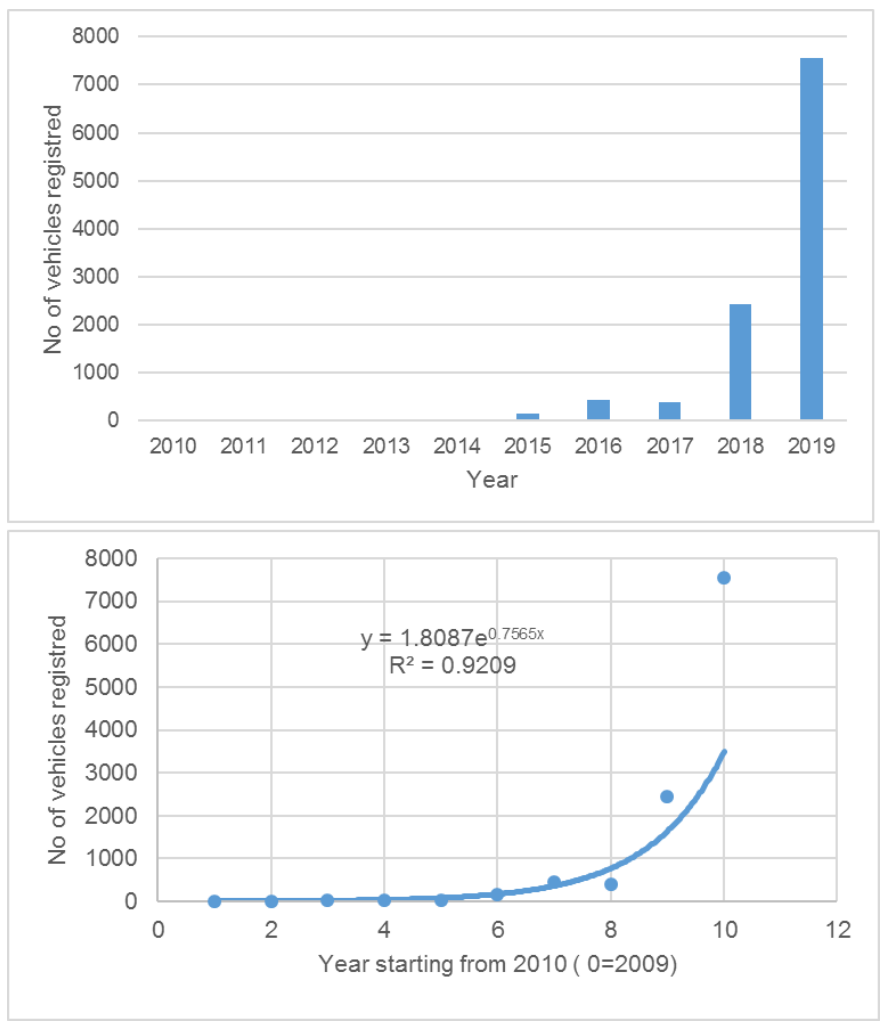

Figure 8. Number of Hybrid vehicle registered in Mexico MAVM area (data source: Dirección General de Registro Público de Transporte), a section of Secretaría de Movilidad de la Ciudad de México (SEMOVI)).
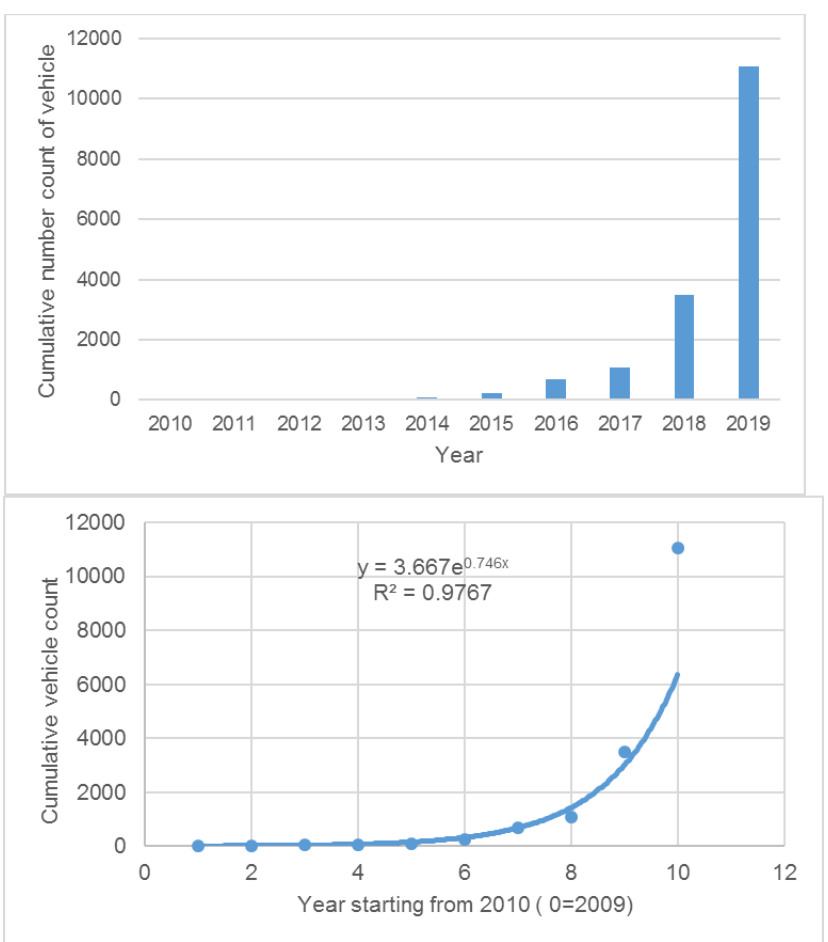

Figure 9. Total number of Hybrid vehicles in Mexico MAVM area.

\section{CO2 and Emission reduction by converting ICE hybrid to hydrogen fuel cell vehicle and the $\mathrm{H} 2$ supply required}

\section{Scenario 1}

Two possible scenarios have been considered for projecting the amount of hydrogen required for running fuel cell vehicle in Mexico City. The emission values and CO2 level of Prius, which is shown in Table 1, are used as a base for estimating the total amount of emission reduction possible if the internal combustion engine in the hybrid vehicles is replaced with the hydrogen fuel cell. The total number of hybrid vehicles registered in the Mexico City from 2010 and the total number of hybrid vehicles in MVAM area shown in Figures 7 and 8 are used in this calculation. The total number of hybrid vehicles registered is 11058 out of this 4890 vehicles are Prius Hybrid electric vehicles. Therefore, Prius is chosen as base vehicle for this scenario analysis. The average distance travelled by passenger vehicle per day in Mexico Metropolis is taken as $6.5 \mathrm{~km}$ based on Erick Guerra [44]. The estimated amount of $\mathrm{CO} 2, \mathrm{CO}$, THC and NOx from existing hybrid vehicles in $\mathrm{kg}$ per year as shown in Table 2. If the internal combustion engine is replaced by fuel cell vehicle over the next 10 year, the amount of pollutants that can be reduced in order to improve the local air quality and also amount of $\mathrm{CO} 2$ that could be reduced over the period is quantified if the current hybrid fleet is converted to work as a FCV fleet from 2020-2030.

Table 1. Emission levels and CO2 base value based on Prius used for estimating total amount for hybrid vehicles equipped with internal combustion engine [45].

\begin{tabular}{|l|l|l|}
\hline $\mathrm{CO} 2$ & $\mathrm{~g} / \mathrm{km}$ & 70 \\
\hline $\mathrm{CO}$ & $\mathrm{mg} / \mathrm{km}$ & 131 \\
\hline THC & $\mathrm{mg} / \mathrm{km}$ & 34 \\
\hline NOx & $\mathrm{mg} / \mathrm{km}$ & 16 \\
\hline
\end{tabular}

This scenario assumes that the ICE in the current hybrid fleet will be replaced by Fuel cell and therefore, the amount of hydrogen fuel supply required based on the Mexico Driving cycle representing different trip duration has been estimated using the powertrain simulation and the result are given in Table 3.

Table 2. Scenario 1.

\begin{tabular}{|c|c|c|c|}
\hline \multicolumn{2}{|c|}{$\begin{array}{l}\text { Number of hybrid vehicle in } \\
\text { MAVM as on } 2019\end{array}$} & & 11058 \\
\hline \multicolumn{2}{|c|}{$\begin{array}{l}\text { Total distance travelled by } \\
\text { Hybrid vehicle per day } \\
\text { (average) }\end{array}$} & $\mathrm{km}$ & 71877 \\
\hline \multicolumn{2}{|c|}{ Emitted per year } & & $\begin{array}{c}\text { Based on Average distance } \\
\text { travelled }\end{array}$ \\
\hline $\mathrm{CO} 2$ & $\mathrm{~kg}$ & & 1836457 \\
\hline $\mathrm{CO}$ & $\mathrm{kg}$ & & 3437 \\
\hline THC & $\mathrm{kg}$ & & 892 \\
\hline $\mathrm{NOx}$ & $\mathrm{kg}$ & & 420 \\
\hline
\end{tabular}


Table 3. Hydrogen fuel required based on MAVM drive cycle per day.

\begin{tabular}{|c|r|r|}
\hline Drive cycle & & \multicolumn{2}{|c|}{$\begin{array}{c}\text { Based on Average } \\
\text { distance travelled }\end{array}$} \\
\hline CMV-A-584 & $\mathrm{kg}$ & 172 \\
\hline CMV-A-1284 & $\mathrm{kg}$ & 473 \\
\hline CMV-A-1683 & $\mathrm{kg}$ & 710 \\
\hline
\end{tabular}

\section{Scenario 2}

The second scenario assumes that similar number of hybrid vehicle will be converted as a fuel cell vehicle or positive policy framework will enable the public to procure hydrogen fuel cell vehicles from 2030 . Therefore, if the existing vehicles are converted to fuel cell vehicle by 2030 and the similar number of fuel cell vehicles are added to the fleet from 2030-2040 the amount of reduction in CO2 and CO, THC and NOx and required amount of hydrogen supply for meeting the demands can be estimated based on the procedure explained in the previous section. The expected reduction in pollutants is given in Table 4 and the fuel supply required is given in Table 5 for the second scenario.

Table 4. Scenario 2.

\begin{tabular}{|c|c|c|c|}
\hline $\begin{array}{l}\text { Number of hybrid vehicle in } \\
\text { MAVM (projected) for } \\
\text { conversion to FCA from } \\
\text { 2030-2040 }\end{array}$ & k2116 \\
\hline $\begin{array}{l}\text { Total distance travelled by } \\
\text { Hybrid vehicle per day } \\
\text { (average) }\end{array}$ & $\mathrm{km}$ & 143754 \\
\hline Emitted per year & $\mathrm{kg}$ & & $\begin{array}{l}\text { Based on average } \\
\text { distance travelled }\end{array}$ \\
\hline $\mathrm{CO} 2$ & $\mathrm{~kg}$ & & 3672915 \\
\hline $\mathrm{CO}$ & $\mathrm{kg}$ & & 6874 \\
\hline $\mathrm{THC}$ & $\mathrm{kg}$ & & 1784 \\
\hline $\mathrm{NOx}$ & & & 840 \\
\hline
\end{tabular}

Table 5. Hydrogen fuel required based on MAVM drive cycle per day.

\begin{tabular}{|c|r|r|}
\hline Drive cycle & & \multicolumn{2}{|c|}{$\begin{array}{c}\text { Based on Average } \\
\text { distance travelled }\end{array}$} \\
\hline CMV-A-584 & $\mathrm{kg}$ & 343 \\
\hline CMV-A-1284 & $\mathrm{kg}$ & 945 \\
\hline CMV-A-1683 & $\mathrm{kg}$ & 1420 \\
\hline
\end{tabular}

\section{Conclusion}

The present work modelled and validated a Fuel cell vehicle using Powertrain simulation software. Representative drive cycles for Metropolitan Area of the Valley of Mexico were developed and used for estimating amount of hydrogen consumed by the vehicle in $\mathrm{kg} / 100$ $\mathrm{km}$. Using vehicle emission levels of Prius as a base value, the expected reduction in $\mathrm{CO} 2, \mathrm{CO}$ and $\mathrm{THC}$ and $\mathrm{NOx}$ if the internal combustion in the hybrid vehicle is replaced with the fuel cell is identified. If the ICE engines in the existing hybrid vehicle fleet are replaced by fuel cell vehicle based on scenario 1, it will result in reduction of 1836 tons of $\mathrm{CO} 2$ per year from MVEM region. The analysis showed that significant amount of reduction in $\mathrm{CO} 2$ and other pollutants could be achieved by this technological intervention approach. The reduction in $\mathrm{CO} 2$ level could be doubled if the phased introduction of this policy is implemented in Mexico. This approach also enables us to propose the necessary planning required for meeting the fuel demand to service the hydrogen fuel cell vehicle. The benefit of moving towards hydrogen fuel cell vehicle for meeting local air pollution targets and reduce the transition period for moving from internal combustion engines to electrification can exceed the battery operated fully electric vehicle.

\section{References}

1. Hardman, S., Shiu, E., and Steinberger-Wilckens, R., "Changing the fate of Fuel Cell Vehicles: Can lessons be learnt from Tesla Motors?", International Journal of Hydrogen Energy 40(4):16251638, 2015, doi:10.1016/j.ijhydene.2014.11.149, ISSN:0360-3199.

2. Heywood and others, "On the road toward 2050, Potential for substantial reductions in Light duty vehicle energy use and green house gas emissions", MIT report. 2015. http://web.mit.edu/sloanautolab/research/beforeh2/otr2050/. ISBN: 978-0-9962185-0-4

3. Hardman, S., et al., "Consumer attitudes to fuel cell vehicles post trial in the United Kingdom", International Journal of Hydrogen Energy 41(15):6171-6179, 2016, doi:10.1016/j.ijhydene.2016.02.067, ISSN:0360-3199.

4. Archer, S. A., and Steinberger-Wilckens, R., "Systematic analysis of biomass derived fuels for fuel cells", International Journal of Hydrogen Energy 43(52):23178-23192, 2018, doi:10.1016/j.ijhydene.2018.10.161, ISSN:0360-3199.

5. Fletcher, T., Thring, R., and Watkinson, M., "An Energy Management Strategy to concurrently optimise fuel consumption \& PEM fuel cell lifetime in a hybrid vehicle", International Journal of Hydrogen Energy 41(46):21503-21515, 2016, doi:10.1016/j.ijhydene.2016.08.157, ISSN:0360-3199.

6. Valente, A., Iribarren, D., and Dufour, J., "End of life of fuel cells and hydrogen products: From technologies to strategies", International Journal of Hydrogen Energy 41(46):20965-20977, 2019, doi:10.1016/j.ijhydene.2019.01.110, ISSN:0360-3199.

7. Forysinski, P., et al., "Development and use of a mixed-reactant fuel cell", Journal of Power Sources 414:366-376, 2019, doi:10.1016/j.jpowsour.2018.12.081, ISSN:0378-7753.

8. Wu, W., et al., "Optimization of a Multi-tube Annular Membrane Methanol Reformer for Fuel Cell-Powered Vehicles", Energy Procedia 152:661-666, 2018, doi:10.1016/j.egypro.2018.09.227, ISSN:1876-6102.

9. Wu, Z., et al., "Dynamic modelling of a NG-fueled SOFC-PEMFC hybrid system coupled with TSA process for fuel cell vehicle", Energy Procedia 158:2215-2224, 2019, doi:10.1016/j.egypro.2019.01.167, ISSN:1876-6102. 
10. Fukuzumi, S., "Production of Liquid Solar Fuels and Their Use in Fuel Cells", Joule 1:689-738, 2017, https://doi.org/10.1016/j.joule.2017.07.007

11. Ali Saadabadi, S., et al., "Solid Oxide Fuel Cells fuelled with biogas: Potential and constraints", Renewable Energy 134:194-214, 2019, doi:10.1016/j.renene.2018.11.028. ISSN:0960-1481.

12. Kwon, S., Kang, S., and Kim, T., "Development of NaBH4-Based Hydrogen Generator for Fuel Cell Unmanned Aerial Vehicles with Movable Fuel Cartridge", Energy Procedia 158:1930-1935, 2019, doi:10.1016/j.egypro.2019.01.443, ISSN:1876-6102.

13. Chu, Y., et al., "Design of energy and materials for ammoniabased extended-range electric vehicles", Energy Procedia 33:30643069, 2019, doi:10.1016/i.egypro.2019.01.991, ISSN:1876-6102.

14. Weydahl, H., International Journal of Hydrogen Energy 2019. https://doi.org/10.1016/j.ijhydene.2019.05.035. ISSN:0360-3199.

15. Song, K., et al., "Multi-mode energy management strategy for fuel cell electric vehicles based on driving pattern identification using learning vector quantization neural network algorithm", Journal of Power Sources. 389:230-239, 2018,

doi:10.1016/j.jpowsour.2018.04.024, ISSN:0378-7753.

16. Schlatter,M, J., "An evaluation of fuel cell systems for vehicle propulsion", SAE Technical Paper 670453, 1967, https://doi.org/10.4271/670453.

17. Kendall, M., "Fuel cell development for New Energy Vehicules (NEVs) and clean air in China", Progress in Natural Science: Materials International 28(2):113-120, 2018, doi:10.1016/j.pnsc.2018.03.001, ISSN:1002-0071.

18. Mayyas, A. and Mann, M., "Emerging Manufacturing Technologies for Fuel Cells and Electrolyzers", Procedia Manufacturing 33:508-515, 2019, doi:10.1016/j.promfg.2019.04.063, ISSN:2351-9789.

19. Cortés, L. N., et al., "Reva Electric Vehicle Conversion to a Hydrogen Fuel Cell Powered Vehicle", Energy Procedia 29:325-331: 2012, doi:10.1016/j.egypro.2012.09.039, ISSN:1876-6102.

20. Fragiacomo, P. and Piraino, F., "Energy performance of a Fuel Cell hybrid system for rail vehicle propulsion", Energy Procedia 126:1051-1058, 2017, doi:10.1016/j.egypro.2017.08.312, ISSN:18766102.

21. Tokimatsu, K., et al., "Energy modeling approach to the global energy-mineral nexus: A first look at metal requirements and the $2{ }^{\circ} \mathrm{C}$ target", Applied Energy 207:494-509, 2017, doi:10.1016/j.apenergy.2017.05.151, ISSN:0306-2619.

22. Alavi, F., et al., "Fuel cell cars in a microgrid for synergies between hydrogen and electricity networks", Applied Energy 192:296-304, 2017, doi:10.1016/j.apenergy.2016.10.084, ISSN:03062619.

Page 9 of 10
23. Guirong, Z., Houyu, L., and Fei, H., "Propulsion Control for Fuel Cell Electric Vehicle", Procedia Environmental Science.10(A):439443, 2011, doi:10.1016/j.proenv.2011.09.072, ISSN:1878-0296.

24. Cipollone, R., et al., "Model based Design and Optimization of a Fuel Cell Electric Vehicle", Energy Procedia 45:71-80, 2014, doi:10.1016/j.egypro.2014.01.009, ISSN:1876-6102.

25. Mohammedi, M., et al., "Fuzzy Logic and Passivity-based Controller Applied to Electric Vehicle Using Fuel Cell and Supercapacitors Hybrid Source", Energy Procedia 50:619-626, 2014, doi:10.1016/j.egypro.2014.06.076, ISSN:1876-6102.

26. Becherif, M., et al., "Multi-stack Fuel Cells Powering a Vehicle", Energy Procedia 74:308-319, 2015, doi:10.1016/i.egypro.2015.07.613, ISSN:1876-6102.

27. Giorgio, P. D., et al., "Model based preliminary design and optimization of Internal Combustion Engine and Fuel Cell hybrid electric vehicle", Energy Procedia 148:1191-1198, 2018, doi:10.1016/j.egypro.2018.08.022, ISSN:1876-6102.

28. Palencia, J. C. G., Araki, M., and Shiga, S., "Energy consumption and $\mathrm{CO} 2$ emissions reduction potential of electric-drive vehicle diffusion in a road freight vehicle fleet", Energy Procedia 142:29362941, 2017, doi:10.1016/j.egypro.2017.12.420, ISSN:1876-6102.

29. Osborne, K. D. and Sulek, M. S., "Ford's Zero emission P2000 Fuel cell vehicle", SAE Technical Paper 2001-01-3454, 2001, doi: 10.4271/2001-01-3454.

30. Sopko, G. M., "Fuel Cell System Experiences in Automotive Applications", SAE Technical Paper 2001-01-2549, 2001, doi: $10.4271 / 2001-01-2549$.

31. Pacey, J. D., "Federal Involvement in Fuel Cell Research and Development for Vehicular Applications", SAE Technical Paper 2002-01-1269, 2002, doi:10.4271/2002-01-1269.

32. Johansson, K. and Alvfors, P., "The Effect of Drive Cycles on the Performance of a PEM Fuel Cell System for Automotive Applications", SAE Technical Paper 2001-01-3454, 2001, doi:10.4271/2001-01-3454

33. Yulianto, A., et al., "Modelling of full electric and hybrid electric fuel cells buses", Procedia Computer Science 112:1916-1925, 2017, doi:10.1016/j.procs.2017.08.036, ISSN:1877-0509.

34. Akula, P. R., et al., "Development of Energy Management Strategies and Analysis with Standard Drive Cycles for Fuel Cell Electric Vehicles", SAE Technical Paper 2012-01-1609, 2012, doi: $\underline{10.4271 / 2012-01-1609}$.

35. Yogesha, S. A., et al., "Development of Hydrogen Fuel Cell Bus Technology for Urban Transport in India", SAE Technical paper 2019-26-0092, 2019, doi:10.4271/2019-26-0092.

36. Ramaswamy, S., Moore, R., and Cunninham, J., "A Comparison of Energy Use for a Indirect Hydrocarbon Hybrid versus a Indirect Hydrocarbon Load-Following Fuel Cell Vehicle", SAE Technical Paper 2004-01-1476, 2004, doi:10.4271/2004-01-1476. 
37. Das, S., "Lightweight Opportunities for Fuel Cell Vehicles", SAE Technical Paper 2005-01-0007, 2005, doi:10.4271/2005-01-0007.

38. Lohse-Bush, H., et al., "Technology Assessment of a Fuel Cell Vehicle: 2017 Toyota Mirai", ANL report ANL/ESD-18/12, Argonne National Laboratory, 2018.

- 39. Pimentel, H. G., and Samuel, S., "Route Selection Strategy for Hybrid vehicles Based on Energy Management and Real Time Drive Cycles", SAE Technical Paper 2018-04-03, 2018, https://doi.org/10.4271/2018-01-0995.

- $\quad$ 40. Bengolea, F., and Samuel, S., "Technology Choices for Optimizing the Performance of Racing Vehicles", SAE Technical paper 2016-04-05, 2016, https://doi.org/10.4271/2016-01-1173.

41. García-Zamudio, E. F., and Hernández-Rito, L. A., "Síntesis de ciclos de manejo vehicular para automóviles en la Zona Metropolitana del Valle de México", B.E. thesis, Facultad de Ingeniería, Universidad Nacional Autónoma de México, México, 2019.

42. Barbosa, F., "Hydrogen Fuel Cell Transit Bus Technology into a Technical-Economical Perspective", SAE Technical Paper 2013-360270, 2013, doi:10.4271/2013-36-0270.

43. Kumar, A. and Sehgal, M., "Hydrogen Fuel Cell Technology for a Sustainable Future: A Review", SAE Technical Paper 2018-01-1307, 2018, doi: $10.4271 / 2018-01-1307$.

44. Guerra, E., "The geography of car ownership in Mexico City: a joint model of households' residential location and car ownership decisions", Journal of Transport Geography 43:171-180, 2015, doi:10.1016/j.jtrangeo.2015.01.014, ISSN:0966-6923.

45. VCA, "Vehicle Certification Agency; data Achieve", https://carfueldata.vehicle-certification-

agency.gov.uk/downloads/default.aspx, accessed Jan. 2020.

\section{Contact Information}

Stephen Samuel, PhD, s.samuel@brookes.ac.uk Rogelio González Oropeza, PhD, rog1950@unam.mx Eduardo Cedillo Cornejo, MSc, quetzalpixqui@tuta.io

\section{Acknowledgments}

The development of driving cycles in Mexico City was supported by UNAM, with the PAPIIT IG 181010 project, as well as the stay of Prof. Rogelio González Oropeza at the Oxford Brookes University for the Programa de Apoyos para la Superación del Personal Académico de la UNAM (PASPA). 